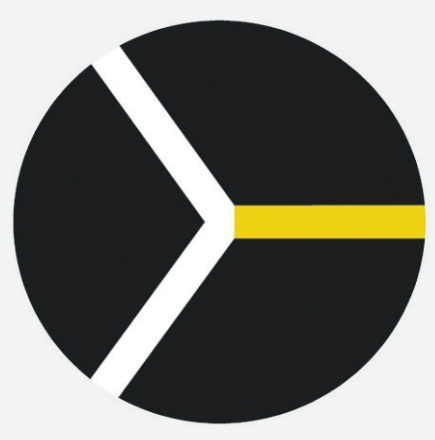

TECHNOLOGY GOVERNANCE

Working Papers in Technology Governance and Economic Dynamics no. 50

THE OTHER CANON FOUNDATION, NORWAY

TALLINN UNIVERSITY OF TECHNOLOGY, TALLINN

RAGNAR NURKSE SCHOOL OF INNOVATION AND GOVERNANCE

CONTACT: Rainer Kattel, kattel@staff.ttu.ee; Wolfgang Drechsler, drechsler@staff.ttu.ee; Erik S. Reinert, reinert@staff.ttu.ee

\title{
Three Paradigms of
}

\section{Governance and Administration: Chinese, Western and Islamic}

Prof. Dr. Dr.h.c. Wolfgang Drechsler

Chair of Governance, Ragnar Nurkse School of Innovation and Governance

Tallinn University of Technology

wolfgang.drechsler@ttu.ee

April 2013

"Three Paradigms of Governance and Administration: Chinese, Western, and Islamic", Society and Economy, vol. 35, no. 3 (Fall 2013), in press. 
The title of this essay is programmatic: I will attempt to suggest and tentatively conceptualize and that there are (at least) three paradigms of governance and especially public administration (PA). Briefly put, this means that there is not one global best (practice of) PA, but that what we call global PA is actually Western 'PA - and, today, that means to a large extent Anglo-American PA. If we follow Bouckaert's (2011) suggestion that PA has two dimensions, equity (goals) and performance (mechanics), inextricably linked though they may often be, we call this global PA "good PA" if it is both "working" and "ethical". With paradigms, I first of all mean the potentiality and theory - we may also say possible epistemes - rather than reality and practice as we observe it today of forms of what we can call Non-Western PA (NWPA). It is the availability of the potential that, in light of the reality as it exists, may make this topic relevant.

\section{The problem and the three paradigms}

In many social sciences and humanities disciplines, to say something like that would hardly be novel, and even in economics, amazingly enough, globalization has apparently not led to convergence. (Classically Boyer 1994) But in PA, this is a very unusual observation - here, it is generally if tacitly assumed that there is one good PA, and that this is globalWestern, PA; it is certainly so in scholarship, but even more so in PA reform. (Cf. only Public Administration Review 2010) In other words, countries and places that do not adhere to or at least move towards the global-Western standard (even if this includes significant regional variations) ${ }^{2}$ are somehow remiss; they do not provide optimal PA and thus governance (of which I would say PA is the implementational side; I will not delineate the relation of the two concepts any further). The only excuse they may have is that they are laggards, in transition, but they are expected to eventually arrive at good global(-Western) PA.

Contrary to this, what I would like to suggest is that there indeed are PA solutions to problems that arise from the nature of PA itself, which in turn is based on the fact that, commonly in time and space, more human

\footnotetext{
1 With "West" and "Western", I mean in this PA-centered context Europe as embodied by the core EU, North America, and Australia and New Zealand, with its Greco-Christian-Enlightenment-Scientism legacy plus both production and consumer Capitalism. (But see Winkler 2011) 2 Regarding Asia, see Cheung 2012; Berman 2010.
} 
beings live in society than can be coordinated personally and directly. However, in different contexts, there are also solutions to common problems that are different but not worse, very likely at least some of them even better, and there are adequate, good, indeed excellent solutions that completely depend on a context - understood here as Lebenswelt ${ }^{3}$ - that is neither worse than the one for which Western PA is made, nor moving into the latter's direction, never mind the genuine phenomenon, on many but precisely not all levels of life, of globalization.

The two potential partners of global-Western PA as largely independent paradigms are, I would suggest, Chinese and Islamic PA. (Cf. Painter and Peters 2010,3 ; 19) For the few people dealing with these questions, it is highly contentious whether there may be more, and what the other models might be, ${ }^{4}$ but I would single out these two for now because they, and only they, share a few significant features:

- A large body of theoretical literature

- Centuries of practice

- Strong relevance today

- Most controversially perhaps, a basically unique theory and governance background; not a primarily derivative system.

For the moment, I would suggest that this is most clearly the case with classical Chinese, i.e. largely Confucian, and classical Islamic PA. Because of the "classical" part, we will have to look more at history than is usual in PA - not because of simple notions of legacy and context, ${ }^{5}$ but because my concern, as indicated, is potentiality more than current realization and recognition in contemporary scholarship, which certainly is global-Western. It is, basically, about the honest basis for a convincing narrative, or convincing narratives. Regarding the empirics, this is therefore more of an agenda, rather than being based on research already.

3 Lebenswelt, life world in the sense of the existence of the human person in a phenomenological, Continental-idealist or semiotical sense, is "the sum of non-inheritable information" (Lotman 1971, 167) in which the individual persons, and then by extension the groups of persons, live by their own, however evolving and latent, self-definition, and through which they operate - what defines people is what they let define them. To speak with Nicolai Hartmann (who talks about Geist, which arguably is the manifestation of context), "Nobody invents his own language, creates his own science; the individual, rather, grows into what is existing, he takes it over from the common sphere, which offers it to him." (1949, 460; for a general philosophical discussion of this question, see Drechsler 1997a, 67-69.)

4 The usual contenders would be Russian/Soviet, Hispanic/Latin, Indian, or Japanese. (See also Painter and Peters 2010, 19-30) Even though this will not be agreeable to all readers, I will suggest that the former three are basically Western, the latter is basically Chinese.

5 Going beyond these, see Painter and Peters 2010, 3-16, 237; Yesilkagit 2010, with a very nice heuristic distinction between legacy ideas and legacy structures. 
But why would that be interesting? The abovementioned equation, global = Western = good, can also be extended by the addition of "modern", i.e. global $=$ Western $=$ good $=$ modern. Thus, modernization would equal Westernization, which would be a good thing. But the suggestion that modernization, i.e. any improvement, automatically means Westernization actually delegitimizes the former in those contexts in which Westernization is at least an ambiguous concept for many. Assuming that often, these are contexts which could really benefit from it, to show that the improvement of PA does not automatically mean Westernization, in other words, that modernization is not necessarily Westernization, would be a major accomplishment (as long as we assume that Westernization is either impossible or at least very difficult or not that desirable). It may then easily be that countries which do not follow the global-Western model are not laggards but rather pursue their own path towards good PA. In that case, policy recommendations (often linked to financial incentives) to move towards Western PA benchmarks might be not only misguided, but they may turn out to be highly counterproductive.

But interest vested in the global-Western paradigm is very substantial, both in policy and scholarship, and always has been. Almost 300 years ago, Christian Wolff (1679-1754), the most eminent Continental European philosopher between Leibnitz and Kant and also one of the candidates for the title of founding father of Public Administration as a scholarly discipline, was ousted from his chair at the University of Halle in one of the most celebrated academic dramas of the $18^{\text {th }}$ century. By decree of the King of Prussia, initiated by the Pietist Divinity faculty which saw in Wolff a dangerous rival and an enemy of the faith, Wolff had to leave Prussia within 48 hours or be hung. The immediate cause had been his farewell address as vice rector in 1721 (Wolff 1985) in which Wolff describes Confucianism quite critically, but still more or less as ethically viable. One could, he thus implied, be ethical without being Christian, and indeed without being Western. ${ }^{8}$ Today, the situation is of course

\footnotetext{
6 If one sees democracy and global democratization (cf. Diamond 2013) as Western and Westernization, then the discourse becomes more complicated of course and hinges even more on the performance aspect of governance.

7 A nice parallel are the European countries which some ten or fifteen years ago were still judged according to how close they were "already" to the New Public Management (NPM) (a great example is Bossaert and Demmke 2003) but which, according to Pollitt and Bouckaert, did not follow the NPM at all but rather their own, perhaps even (and in my opinion certainly) better model, that of the Neo-Weberian State (NWS). (See Pollitt and Bouckaert 2004, 99-100. It is actually observing this phenomenon that gave rise to the concept of the NWS to begin with, which later partially transformed from an empirical to a normative model; see Drechsler and Kattel 2009.) 8 Wolff immediately found refuge at the Hessian University of Marburg. As one of the most popular and fashionable teachers in Europe, he increased university-wide matriculation figures within five years by about $50 \%$. Wolff returned to Halle in 1740 after the ascension of the new King of Prussia and admirer of his, Frederick II (the Great). (Regarding Wolff, see Drechsler 1997b)
} 
much more relaxed; penalties for anti-Westernism are much lower, and in many areas of scholarly inquiry, there is actually even the opposite, perhaps even to the point of what has been called "Occidentalism." (Buruma and Margalit 2004) But as mentioned, in PA, this is certainly not the case.

However, during the last half decade or so, two phenomena have weakened the assuredness in and of the West that its solutions are the global ones wherever one goes, and this has slowly reached PA as well. One is the global financial crisis, which has called the Western system into question both as regards setup and performance, including PA (see Drechsler 2011), and another is the re-emergence of China, with a different and altogether, internationally speaking, successful mode of governance. (See Fukuyama 2011, esp. 17-18; Jacques 2011)

Specifically for PA, it is important that this occurs at a time in which it is difficult to offer a cohesive PA paradigm, because there really is none. After the demise of the NPM as the ruling one (see Drechsler 2009b; Drechsler and Kattel 2009), what we are facing is a post-NPM Unübersichtlichkeit with several "paradigmettes", such as the old NPM and the new one (a response to the global financial crisis), traditional Weberianism, NPM-plus concepts such as New Public Governance and its varied permutations as well as Public Value, and Weberian-plus ones, such as the Neo-Weberian State. (See Pollitt and Bouckaert, 2011) So, what is it that the West can responsibly sell?

\section{Three ways of looking at PA}

Altogether, all this would mean that there is such a thing as NWPA, and that this can be good PA, not an aberration or an atavism. But again, there seems to be also a core of good PA that all systems share, and there are plenty of grey zones in between. In order to somehow clarify this vague-sounding scenario, I would (again preliminarily) propose three possible models of trajectories to good PA: Western, Multicultural and Contextual, the latter being what I suggest as most helpful.

The first one is what I have described as the global-Western mainstream: Global $=$ Western $=$ good $(=$ modern $)$. All other traditions, including Chinese and Islamic, would have to eventually converge into the development trajectory of this or else be not just different but worse. One may or may not allow contextual variations, but in principle, the idea is that we know what good PA is, that good PA is univer- 
sal, that by and large this is Western PA, and that this will remain so for the foreseeable times to come.

If one does not buy into this narrative, or at least would like to question it, then the second model would seem to be the obvious, or logical, counter-alternative. This, which we may call Multicultural PA, would hold that there is no such thing as ideal PA as such, that good PA depends entirely on culture and context, never mind on which level, and that the ways there are entirely context-dependent as well and generally not linked to one another. Multicultural PA has, again, the advantage of being politically correct in many contexts (outside of PA); it is prima facie a good alternative to the erroneous simplicities of global-Western PA. However, the problems with this approach are manifold as well, and maybe first of all that, as mentioned and as any NWPA research will very quickly show, there are actually both problems and solutions that are germane to PA, no matter where one looks, and that solutions may be sometimes different across time and space but sometimes very, indeed strikingly, similar indeed. (See Drechsler 2014 regarding Neo-Confucian China)

The third model, the Contextual one, says that there is something like good PA, and although it may be an amorphous entity and a moving target, some solutions are similar at all or most times (e.g. often managerial ones), some are different (e.g. often state-citizen relations); what is good $\mathrm{PA}$ in one context does not have to be in the other; it depends on the circumstances. The key to reaching good PA is to realize where one is coming from at the moment and to be in synch with that, and that means, to realize what the context actually is. Of course, one can look at other systems and learn from there, but in this context, that would necessarily be policy learning, not mere policy transfer. (See Randma-Liiv and Kruusenberg 2012; a recent empirical case study regarding China in line with this is Christensen et al. 2012)

This is the model I recently suggested elsewhere (Drechsler 2013), but this was too simple regarding the label of "good" and misleading by suggesting that, even if moving, there is one such target for PA. First, recalling the Bouckaert 's differentiation between equity and performance (2011; see also 2012 about the bridging of the two via trust), I would say that primarily, "good" in PA means "fulfilling its purpose in a given context" - PA is good when it does what is supposed to do; like the

9 Public Administration Review 2010, in spite of much sophistication of some of the contributions, and recently Gulrajani and Moloney 2012, basically make this point, both for science and for policy; the latter provides also a handy summary of the theory and practice of comparative 'third-world' PA scholarship during the last decades from an Anglo-American mainstream perspective. 
market in an economy, it does not come prima facie with values attached. (Certain forms of PA have certain effects that from certain perspectives have normative connotations, but not more than that.) And this is crucial for "goodness":

The Hatter ... had taken his watch out of his pocket, and was looking at it uneasily ... "Two days wrong! ... I told you butter wouldn't suit the works!" he added, looking angrily at the March Hare.

"It was the best butter," the March Hare meekly replied.

As Peter Heath explained this passage from Lewis Carroll's Alice in Wonderland (1865),

\begin{abstract}
"Good", like its superlative, is often a relative term, meaning "good of its kind", or for its standard purpose, whatever that may be. Failing such a reference, the judgment of goodness is indeterminate, and cannot be applied or debated without risk of confusion. [Thus, the March Hare's statement is right in that the butter was best] as butter goes, no doubt, but not as a mechanical lubricant. (Heath 1974, 68-69)
\end{abstract}

Yet this is not significantly different for ethics, which arguably is set even further outside of PA than performance, which has a direct PA element to it. Especially when we are looking for truly good governance - a cliché term which by now clearly begs the question, good for whom? (see Drechsler 2004) -, it is pivotal to realize this, not least for policy. Aristotle, one of the most quintessentially, definitorially Western philosophers, "the philosopher" in fact, and the father, one could say, of Ethics, made almost exactly this point in his political magnum opus, the Politika, when listing the necessary qualifications for members of a government or administration:

first, sympathy for the constitution as it actually exists; second, competences that are in line with the tasks of their specific office; third, a sense of virtue and justice that is exactly matching those of the state in which they live - because, if the concept of justice is not the same in every state, it is obvious that there must be different kinds. (Arist. Pol. 1309a; V 9)

Second, how to metaphorize good, and that is primarily well-working, PA in context - that there is overlap to some extent and to some extent not? Let us say that all paradigms as proposed participate in some solutions that can be said to form "good PA" in the sense that it does do its job in a decent, and primarily then in an effective and secondarily in a reason- 
ably ethically way, that it does fulfill its "standard purpose" on any possible level, including institutions, people, and concepts, but that in general, these are adapted to context. That means that there may be a small nucleus of well-working PA that almost always works (a), tiny because it must match all performance and all ethics - and (a) is a purely empirical, not a normative concept; then a larger one in which such generally valid principles are adapted to the context and thus work (b); and a third level where solutions work well within a given paradigm but not (necessarily) in any other one (c), which, given the high requirements, would be expected to be the most common case. For our limited model of three paradigms, this would, again tentatively and meant to be overridden, look like this:

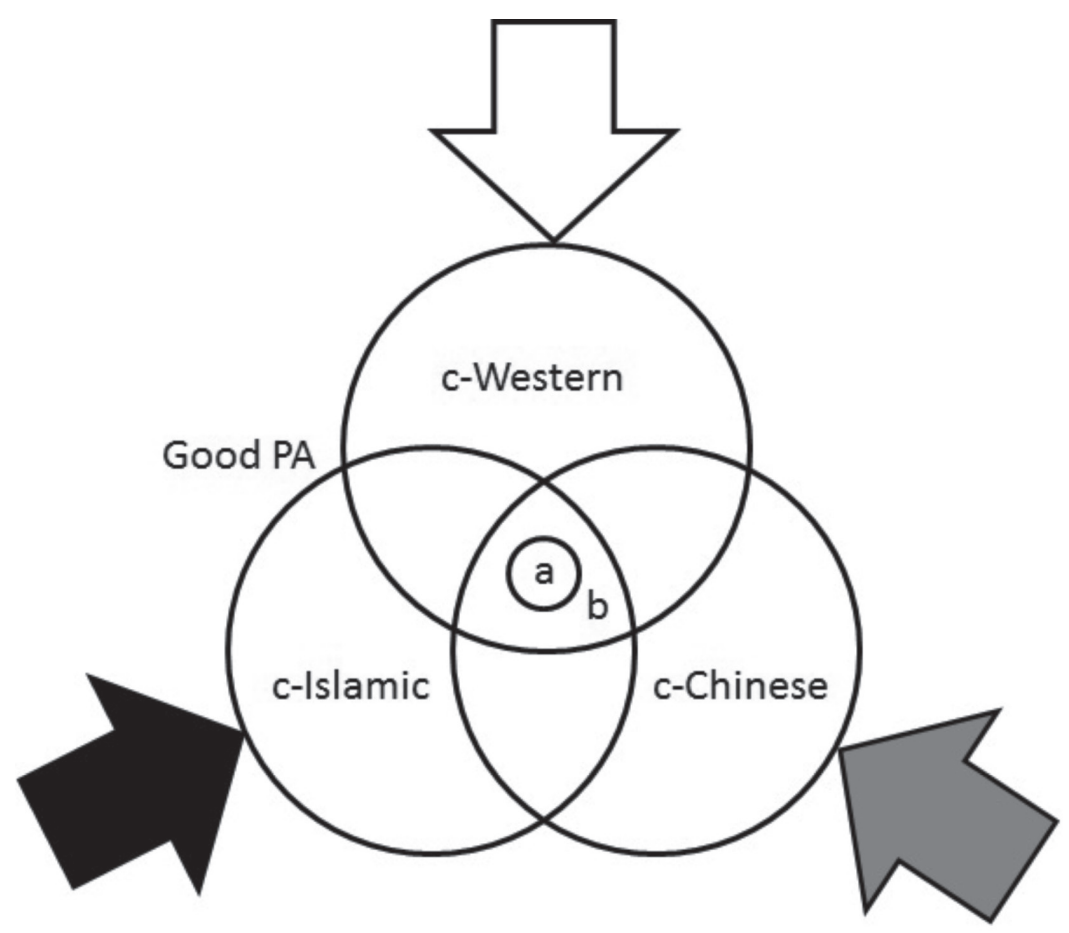

Now, (a) is what is generally assumed to be good PA, and the contextualized second nucleus (b) is what the more sophisticated PA research supports today (although it is not the common view), but our focus is on (c), the postulated spheres of good PA with(in) a certain paradigm each that does not work well, or doesn't have to, in any other one. If this is even partially true, then this does mean indeed that one should not judge, and try to improve, PA on the basis of and towards, the outer (b), let alone the inner nucleus (a), but just ask whether under the circumstances, PA does its job, or is moving thither. 


\section{Chinese and Islamic PA illustrated}

One could even end at this point, but even in the current context, a few brush-strokes sketching out the alternatives to Western PA of classical Chinese and Islamic PA and Governance are in order, because otherwise, the thesis may remain too abstract, and also, because much of this is so counter-epistemic right now for PA that some examples of both equity and performance might be helpful. I have recently described both the Chinese roots of modern PA principles that seem to belong to the second and even first nucleus (Drechsler 2014) and the well-working aspects of Ottoman PA that belong specifically to its own, Islamic paradigm (Drechsler 2013), so I will limit myself to a few interesting examples, partially drawn from these texts. (I will not outline global-Western PA here; we all live in it, and it is recognizable, in spite of the variations.)

\subsection{Chinese PA}

Classical China is not much of a "hard sell" anymore in the West. It hardly ever was for those aware of the sophistication of the culture (think of porcelain, poetry, calligraphy, and so on), even more so perhaps than the legacy of Confucian thought (both well-preserved, as less interrupted by destruction than on the Mainland, in Taiwan/R.O.C.), but, coupled with the economic and political eminence of China today, it means that it is on the difficult side, the more one knows the more so, to relegate China to an inferior global place - let alone that of a 'developing country', never mind the not-even 250-year dip in dominance from which it just emerged. If we look at the last time China arguably "led the world", its name-giver, the Qianlong Emperor (1711-1799), following great Emperors as son and grandson, was not only seen as the most powerful, but also as the most wise, artistically gifted and last but not least just rulers of his time, even by those in the West who could judge (here we remember Wolff). Looking at his private retirement garden alone, his appreciation and collection of antiques, his poetry and calligraphy, next to huge political, economic, and military successes, this is a judgment one cannot easily disagree with. (See Berliner 2010; as well as Elliot 2009; MacGregor 2011,587-592; in spite of some odd judgmentalism in the latter two.)

For PA specifically, it is once again worth pointing out the features whereby China was clearly leading the West. We can assume that even the modern state itself started in China and not in the West (Fukuyama 2011: 18); that this is a state understood very differently from the Western one (Jacques 2011), this is even more interesting. 
China alone created a modern state in the terms defined by Max Weber. That is, China succeeded in developing a centralized, uniform system of bureaucratic administration that was capable of governing a huge population and territory ... China had already invented a system of impersonal, merit-based bureaucratic recruitment that was far more systematic than Roman public administration. (Fukuyama, 2011: 21; see Jacques, 2011: 2)

And this state was enormously successful - so successful that it was not challenged until the mid-19 ${ }^{\text {th }}$ century as regards organization. (Fukuyama 2011, 93)

"It is safe to say that the Chinese invented modern bureaucracy, that is, a permanent administrative cadre selected on the basis of ability rather than kinship or patrimonial connection." (Fukuyama 2011: 113). What is hard to fathom even for someone with a Weberian or French-style étatiste background is the importance the state and thus PA had in the peoples' mind and understanding - something that is, if in much weaker form, still present in the Confucian countries today, and these entail not only China, Taiwan, and Singapore (even though see Bell 2011), but also Japan, South Korea, and Vietnam. (Cheung 2010, 40-43; Painter and Peters $2011,26)$ In several respects, this is also a list of the most successful countries today, and of course, this might not be an accident.

At the core of the Chinese PA system is the Imperial civil service - and, as the Qianlong Emperor used to say, and as we now again realize, "There is no governing by laws; there is only governing by people." (Elliott 2009, 152) The - not always positive, but generally very respected - image of the image of the Chinese civil servant lives on in his specific Western designation, "Mandarin", a term which also entered Western PA parlance for its own independent, highly competent scholar-bureaucrat, especially in the Anglo-American context, generally - until very recently - with a slightly negative if awe-inspiring connotation ("Sir Humphrey Appleby").

As economic history and to some extent presence shows, the dominance of the civil service even in the economy was not harmful to the economy either, nor to technological innovation - maybe because innovation flourishes best within a regulated framework rather than in a free-for-all tumble -, although how one judges that depends on one's own economic faith. ${ }^{10}$ And that even pertains to creativity in the wider sense -

10 The neo-liberal "state-hate" world view is a genuine ideology and will not disappear just because of the cognitive dissonances brought about by, e.g., the global financial crisis or China being by 2013 the leading export nation globally; http://www.bloomberg.com/news/2013-0209/china-passes-u-s-to-become-the-world-s-biggest-trading-nation.html 
MacGregor, in the context of describing the creation of a Han Dynasty lacquer cup, even speaks of Chinese Imperial "bureaucracy as a guarantee of beauty." (2011, 219)

The civil service was created by the famous civil service exam, the longest-continuing PA exam or probably educational institution generally in the history of humankind and the first large-scale competence-based test for anything, which was abolished in 1904, after altogether 13 centuries, "in the name of 'Westernization'." (Elman 2000: xxxv; see Miyazaki 1981: 125) It largely consisted of a very open written exam, radically narrowing the group in different stages, which entailed the formal discussion of the great Confucian Classics; it remained largely stable over the centuries and is thus often seen as too formal and abstract. (On the exam, see briefly and accessibly still Miyazaki 1981; also now Elman 2000, with a strong sociological bias.)

And the exam had its very good sides: It objectivized and was much better than nothing; it was a meritocratic test and thus potentially the only way to counteract the nepotism which has always been seen as a problem in China and which is, if one will, a collateral of strong family ties, which in turn is one of the deciding features of Chinese context. As Fukuyama says, "the natural human propensity to favor family and friends - something I refer to as patrimonialism - constantly reasserts itself in the absence of countervailing incentives." (2011: 17; see Michels, 1911: 13-14) In China, this seems to be the case more so than elsewhere - today especially as compared to the West.

And if there had to be standard texts upon which to base the exam, the Neo-Confucian Four Books were not the worst choice. The potentially quite subversive nature of these texts towards any oppressive, irresponsible regime is very clear even for the casual reader - especially in the Mencius. (See Gardner 2007 for a handy selection; regarding Mencius, first of all Book 1B6, 1B8 [Mencius 2008: 24, 26.]) In addition, the standard canon means that passing the exam was possible by everyone (at least in principle); it contributed to the State being perceived as an "us" and not a "them"; in its objective continuity and transparency, it transported that the process and thus the State was basically not corrupt; and last but not least, it really did result in there being no recruitment problem for the Chinese civil service upon which the country depended so much.

How incredibly important the civil service exam was in China is to be seen from the high esteem in which it, and success in it, was held in Chinese life. This is because becoming a civil servant was simply the highest position one could aspire to - "the one and only career that mattered in impe- 
rial China" (Elliott 2009, 4), one that granted prestige and wealth both to the individual and to his family, even to his place of origin. That the examination was done with the personal involvement of the Emperor himself, who personally graded the final top essays (see Miyazaki 1981: 81-83), unthinkable in the West, shows its centrality for the state system and the esteem in which the process, and thus civil-service selection, was held.

The centrality of the exam goes so far that there exists, as a perennial topic in Chinese literature, art, opera, and so on the trope of the young hero travelling to the examination and being distracted by some adventure. The 2011 Gordon Chan movie "Mural", based on older stories, has a hero a young man whom his true love, the eventual high priestess or queen of a Shangri-La like temple of virgins in a parallel world, sends back to his own one because after all, he has to take the civil service exam and from that he should not be distracted.

Mandarins, in Chinese popular religion and not only in Confucianism (which to a practical extent has turned into a religion as well), can even become deities, and not infrequently. The perhaps most famous example, although often overlooked, is the group of three men, gods, and stars at the same time that many Westerners have encountered in Chinese restaurants or shops. They are called Fu Lu Shou, and they signify happiness or good luck, prosperity also in the status and material sense, and long life and health, respectively. (See generally Fong 1986) Both Fu and Lu wear Mandarin garb, Fu that of a more minor or retired official, Lu that of a courtier especially the typical hat with flaps, the wusha mo or zhanjiao fotou, and both go partially back to, and now are closely associated with, people who were civil servants. (Fong 1986: 186-190, 193) It is significant that Fu Lu Shou developed into patron gods not only of the people, but also precisely of the aristocracy and the scholar-officials, and even the Emperor himself. $(190 ; 196)$ Significantly enough, Fu - originally Yang Cheng - became a deity not for compliance with the Emperor but for resistance - he dared to oppose the Emperor who had asked for midget children from his province to be sent to the court for amusement as jesters, which Fu refused out of compassion and a sense of genuine duty. Hence probably his association with good luck for (and later through) the family. (Fong 1986: 186)

This takes up, not coincidentally but precisely, the strong Chinese tradition, at the very core of Confucianism, that the ruler must deliver, i.e.

11 See http://movies.cultural-china.com/movie.php?movie id=18

12 See also mi-le-fo.thetempleguy.com/figures/fulushou.htm 
procure at least peace and food for its people - if not, he does not have the "Mandate of Heaven" (that is the significance of this concept) and can be replaced, even legitimately killed. (See McGregor 2011: 151 for a nutshell definition, and the Mencius references supra.) That the bureaucracy actually shared the power, in a sense, of the Emperor and the court (Cheung 2010, 38-40), and that over time, ministerial councils established themselves and bureaucratized decision-making (Bartlett 1991, esp. 270-273, 277-278), is neither surprising nor specific - that is what one would expect in any PA context.

Corruption, as was mentioned, has always been an issue in China, and remains so (Osnos 2012 is a great example); it is even often seen as one of the main obstacles to effective Party rule and thus governance of China today. And while corruption is a cultural-contextual phenomenon, and so the definition of which cannot be easily transferred from one paradigm to the next (cf. Urinboyev 2011), and, again, in China it is partially the dark side of close family ties, corruption as such is by definition a problem, because it means things are not done the way they should be. But it is a problem that permeates all PA systems, and those we think of as historically particularly non-corrupt - the Venetian Republic, Prussia around 1900 - had to pay their price for it. The point in our context is that corruption in China is not something that has just been noted from the outside, but that was always recognized as an issue, and thus it is something that can be managed and contained from the inside, both regarding equity and performance, ethics and mechanics - the Civil Service Exam being the primary grand example. Introducing a system that would just "outlaw" family responsibility would hardly be very promising. As regards the awareness, in front of the Beijing Confucius temple, right next to the Imperial Academy, the center of the civil service examination and one of the most enchanted places of PA history anywhere in the world, there is a cypress that famously kicked off the hat of a corrupt official with a branch, who was thus seen as proven guilty and later executed.

And in spite of all tradition and tradition-minded tradition for which classical China has so often been excused, not least by its own (s.v.v.) Young Turks, as in all PA paradigms, PA reform is a red ribbon going through Chinese history. Wang Anshi (1021-1086), well-known as one of the greatest statesmen of classical China, with his 1058 Wan Yan Shu (Memorandum of a Myriad Words; 1935), is one of the first Public Management authors in the modern sense, if not the first. This is so because Wang addresses still current concerns of civil service - selection, training,

13 See http://en.wikipedia.org/wiki/Beijing Temple of Confucius 
motivation, remuneration -, often even by presenting solutions that are completely in line with what they would be from today's perspective, discussing questions, i.a., of performance pay, benchmarking, and managerial trust. But this text is a PA reform program, including large segments criticizing the too impractical Civil Service Exam. Many of Wang's changes were implemented, many rolled back, as is usual in PA reform. For the current general argument, it is especially important that he does present an excellent corpus of Neo-Confucian PA, mostly human resource management, on a theoretically justified, empirically sound, and realistic, contextualized level that penetrates all three spheres of good PA mentioned supra. (A survey is Drechsler 2014)

But finally, how important is Confucianism really today in China? Is it the key to understanding the country or just folklore for ill-informed Westerners? Is there even something we can call Confucianism, or are there so many interpretations and hybrids that we cannot responsibly even use the label? If we allot Confucianism at least some significance and cohesion - and my personal experience is that one definitely should do that - the scope of it for current governance is perhaps best expressed by the Confucius statue in Tiananmen Square. Facetiously speaking, sometimes it is there in the front of the new museum, sometimes inside in a courtyard; it depends which faction in the government is exercising its will at the moment, and for some old-line Communists, Confucius is reactionary and even anathema. (Siemons 2010; 2011; Fähnders 2011) The real Westernizers don't like him very much either - Max Weber, the most important PA scholar ever, belonged to those who blamed China's "backwardness" on his "reactionary" philosophy. (1986, 430-458) But the New Confucians do like him, and they are very likely gaining in importance. (Bell 2010) What can be said in any case is that the relevance of Confucian governance in mainland China, as well as in all the Confucian countries of Asia, is infinitely larger than that of Confucian PA as embodied, for instance, by Wang Anshi, but that there is no reason for the latter not to be rediscovered and redeployed - a convincing narrative can certainly be developed from a genuine basis. The dynamics of global as well as local time and circumstances surely appear to go into this direction.

\subsection{Islamic PA}

Even more immediate in Europe, and certainly in Central and Eastern Europe (CEE), is Islamic PA and Governance, both because of legacy and presence. And yet, although a significant part of the area shares an Islamic, and that means Ottoman, PA element, studying context and practice of Islamic Public Administration is totally neglected, in the CEE region and beyond. (Drechsler 2013) If it is mentioned, then usually the 
Islamic times and institutions, indeed the entire context, are seen as obstacles to modern PA and to Europeanization, as stumbling blocks on the way to good PA; usually, they are cavalierly dismissed in a footnote.

Ironically, for those who do see a relevant topic here, as with Confucianism, yet even more strongly, the first question raised is, is there such a thing of Islamic PA; is it not already Orientalism to suggest that there might be? Experts are split on this issue, and many good reasons speak against referring to Islamic anything except Islam itself. ${ }^{15}$ We could bypass this issue elegantly by only addressing Ottoman PA in the current context, which will anyway be the main focus. And yet, for our current concern, for the third paradigm of PA and governance, and in fact for showing the uniqueness yet specific quality of Islamic PA, to talk about Islam as such does, in my judgment, more harm than good because of its larger scope and its applicability, if to a lesser extent, to the nonOttoman sphere.

One aspect that speaks for Islamic PA as such is that the people in the Islamic countries themselves would overwhelmingly say that Islam Islam as such, whatever their own tradition - matters, and that it matters very much - often to the chagrin of Western observers who want to bring Western-style democracy to these countries and then note that election victories go to Islamic parties, not to people who think like themselves. (Cf. Lerch 2012; Bauer 2012, 401-404) The hypothesis would thus be that Islam - being such a strong determinant of context, of the world in which people live and the systems that they build there and that emerge - has had, and still has, a non-incidental, indeed important and actually crucial impact on how the public sphere is organized and even managed. Thus, one of the most important variables for PA - not only governance - in Islamic countries would be Islam, not just the national tradition, even if (albeit less so) the society in question is quite secular.

Regarding the substance of Islamic PA and Governance, there is a large traditional and still viable literature on the governance aspect, to be sure. For instance, the Nizam al-Mulk (1018-1092) and his Siyāsatnāma (The Book of State Art / of Governance) (1960) present us with a specific,

\footnotetext{
14 In Vintar et al. 2013, beyond my own essay (Drechsler 2013) which talks about this deficiency, Islamic PA is not mentioned at all, and the Ottoman legacy is dealt with in one other essay, where it is assumed to be negative, based on one earlier unspecific reference. (Kostadinova and Neshkova 2013) And this is a book which is summarizing the past twenty years of PA and PA research in Central and Eastern Europe, Central Asia, and the Caucasus. (I am one of the co-editors.)

15 E.g., Thomas Bauer has recently attacked this position with verve as an "Islamicization of Islam", as pretty much the root, and a primary tool, of all evil in misunderstanding both Islam and the countries where this is the faith of the land. (2011, esp. 192-223)
} 
workable concept of state administration that may be as different from the usual Western recommendations for improving the governance of the Central Asian and Middle Eastern countries as it may be superior in realism and applicability. One important example both regarding equity and performance is the strong emphasis on the absolute non-delegatability of responsibility for those over whom one rules. (1960, II, IV, VI) This was seen as a key feature also of Islamic PA, even in the West, for many centuries, although today it is generally forgotten. (Cf. Hebel in Stolleis 2003, 81-85)

\subsubsection{Ottoman $P A$}

For the purposes of this essay, however, let us now focus specifically on the Ottoman Empire. There are many good reasons for this well beyond specificity, communicability and theoretical validity: Because of its centrality for much of the CEE region, especially in its Western Muslim part, but also in the countries it formerly fought and often conquered, such as Hungary; because of its sophistication in PA and public policy, especially on the practical level; because its successor, modern Turkey, is becoming, or actually has become, the powerhouse in the former Imperial region again (see just Aras 2012); because the centuries-long, at best, questionable track record of Westernization as well as Western interventionism in the region and in Turkey itself (see Schulz 2011, esp. 487); and maybe also because today's radical Islamicism is to a large extent based on a fundamentalist movement against the Ottomans. (See Kadri 2011, 123125; Finkel 2007, 411-412) Not least importantly, to reevaluate Ottoman legacies and Ottoman PA in CEE is one of the most controversial topics in this context one could pick up, and therefore it is a worthwhile one. The question of whether there is such a thing as Islamic PA at all and especially whether it is a good or bad legacy locally largely evolves, in our current regional context, around this subject matter. In other words, even beyond the current search for potentiality, Ottoman PA as Islamic PA is a central PA narrative that is about history, but not in itself historical at all. (Cf. Sindbaeck and Hartmuth 2011)

Especially in the last decade or two, the Ottoman Empire has been reassessed by historians and sociologists as "not so bad" in many ways, quite to the contrary of the clichés that various legacies - self-interested, more often than not - have so far promulgated. (A good non-post-colonial introduction to Ottoman history is Finkel 2007) And these reassessments have occasionally included governance. (See e.g. Barkey 2008; Hanioglu 2008) To use the Weberian term, ironically enough, the Sultan's rule was in general precisely not "sultanistic", a form of rule that is "nicht sachlich rationalisiert, sondern es ist in ihr nur die Sphäre der freien Willkür und 
Gnade ins Extrem entwickelt." (Weber 1922, 134; see 133-134; Chehabi and Linz 1998, 4-7) In addition, shifts in how we see governance and PA generally have also contributed to new possibilities of how to assess Osmanian rule and administration. Merilee Grindle's concept of Good-enough Governance $(2004 ; 2007)$ is one of the most important ones in this context, underlining that very often, governance is about achieving minimal workability of a system against the odds of heavy policy constraints, rather than achieving (global-)Western standards ("getting to Denmark"; Fukuyama 2011, 14), assuming that those are actually universally desirable.

Like its Chinese counterpart, Ottoman PA was constantly under reform, too - perennially modernizing at least since the late $18^{\text {th }}$ century (see Findley 1980; Heper 2001, esp. 1021-1022) - and perhaps the ideal case study for such an effort under such circumstances. The Westernizing variant of this modernization effort, in its core time known as the Tanzimat reforms and even the Tanzimat era (1839-1876), was, however, also a reaction to Western pressure, which partially contributed to its illegitimacy in the eyes of many of the citizens. (Ansary 2009, 285288) To thus see the successor paradigm, Hamidism (1876-1908), the governance reforms and reactions to outside and inside pressure by the last powerful Sultan, Abdülhamid II., as a less Western but more contextual form of modernization (see Hanioglu 2008, 123-129; Finkel 2007, 488-501) is one of the more recent and more controversial trends in Ottoman governance reevaluation and, I think, very likely correct. (Examples include the refocus on the Sultan's role as Caliph, the dexterous use of media and communication technology, the emphasis on personal loyalty and the purposeful creation of the ideology of Ottomanism; see already Haslip 1973 [1958], passim; generally, Reinkowski 2005, 14-29)

These newly apparent aspects of the Ottoman Empire, however, have not made it yet to PA history, let alone PA studies generally. ${ }^{16}$ To the contrary: Basically, as mentioned already, in CEE, the Ottoman and thus Islamic legacy is always seen as bad, because the fight against the Ottomans is an - often the central - identity-creating myth of many CEE countries. Differences in administrative and life quality are still excused today by saying

\footnotetext{
16 The obverse is, however, also very often true: Historians who deal with PA, from and concerning either context, often seem unaware of the most basic principles of and discussions within PA as a scholarly discipline, and when they are, they frequently seem one or two paradigms behind. In the last decade or two, some cultural historians of the state, such as Barbara Stolberg-Rilinger, have even questioned, for instance, whether it is possible to speak about such a thing as PA regarding "pre-modern" times at all. (See "Tagungsbericht Herrschaft und Verwaltung in der Frühen Neuzeit. 19.10.2012-20.10.2012, Essen" in: H-Soz-u-Kult, 24 January 2013, http://hsozkult.geschichte.hu-berlin.de/tagungsberichte/id $=4603$ )
} 
that one part was Western and the other one Turkish. (Cf. Sindbaeck and Hartmuth $2011,1,5)$ It has however been claimed that the one exception is Hungary: There is a modern monument (also) for Süleyman the Magnificent in Szigetvár - who died there in battle, together with the Hungarian commander, who perished as well -; something, it has been said, that would be "quite unthinkable elsewhere in Southeast Europe." (3)"

Ottoman PA shares with Confucian PA two crucial features for reevaluation today: Its promotion primarily via the economic success of the main carrier country, and its less than complete enthusiasm for this legacy by the elites in that country. Among all three main intellectually significant political groupings, extreme Westernizers, Kemalite modernizers, and AKP followers, to praise the governance aspects of the Ottoman Empire, let alone of Hamidism, usually meets with incredulity at best. And while there are some tendencies of a reevaluation of Ottoman history as such among the latter group (cf. briefly Bilefsky 2012; Reinkowski 2011), current Turkish PA and PA reform is not Ottoman at all - it is basically still Kemalite with the reform efforts following old-fashioned NPM tenets. (Filkins 2012, esp. 43; Tuğal 2009, 55-56; Sezen 2011, esp. 339) Principally, however, Turkey is a model case of what the Three Paradigms theory holds: Istanbul is today the largest, most dynamic and most innovative city in Europe - again, and actually one of the three largest municipalities in the world (a fact rarely realized in the West), but the Turkish economic miracle that can be witnessed now did only occur after postOttoman Kemalism (a form of global-Westernism) was rematched with Islam. (See Lerch 2012; Gülen 2012; Tuğal 2009)

\subsubsection{So what?}

But why would this be important? The reassessment of the Ottoman Empire is an ideal case study of the potential policy relevance of what merely looks like a shift in academic conceptualization. Once we appreciate that Constantinople had and has a legacy in the governance and PA of CEE that may be different from others but not necessarily worse, this may eventually give especially the Muslim-majority Balkan countries a freer hand to deal with the possibilities of PA development towards genuine modernization today. In her excellent case study of Albania, Cecilie Endresen has recently shown how a positive Ottoman discourse can and does legitimize even global-Western style progress. (2011, 48-50)

\footnotetext{
17 I think that the reason given for this, "because Hungarian nationalism, at times, cultivated historical connections between 'Hungarians' and 'Turks' because they believed Hungary a part of a wider Eurasian heritage" (Sindbaek and Hartmuth 2011:4) is off; rather, I would say this is so because Hungary was selbstbewußt enough that it could afford giving the Sultan his historical due as well. In addition, jeder stirbt für sich allein.
} 
Of course, such a way of thinking comes with costs attached. For Europe and PA, it does go against the principles of the European Administrative Space; it does go against the mindset that still, even from a liberal and not only from a right-wing perspective, defines Europe almost as "nonTurkey." (See only Böckenförde 2011) And that is the general tradition, of course: Not only CEE, but Europe as such is historically often defined by the struggle against the Turks, and against Islam generally, and this "othering" goes on with a vengeance. The Ottomans are still the "quintessentially other", and Muslims, it sometimes seems, as well.

There is one ironic yet profound effect, however, of the approach to define Europe, and by extension the West, by excluding and contrasting it to Turkey, the Ottoman Empire and Islam: If this is so, then surely it is much more likely that there is indeed something like Non-Western and something we can call Islamic PA, because there must then be something specifically Western, rather than global, in our current system. And that, in turn, confirms the Three Paradigms thesis to some extent.

\section{What is Western?}

Again, the question of the current deliberation is, do we arrive more easily at good, meaning well-working, PA if we realize that there are different contexts and thus, potentially at least, different ways thither, as well as legitimately different goals? If we fail certain places, as is so often the case, for not living up to the standards of globalized-Western PA, is this necessarily the problem of the countries in question, or may it also be the problem of asking the wrong questions and setting the wrong targets?

This is all the more important if we look at the context of development, as many Western countries are currently the more successful ones, which was not really the case about Islamic ones except Turkey very recently (and some Confucian ones less recently). That administrative capacity, institutionally as well as personally, is a condition sine qua non for development is clear. (Nurkse 1952; 1953; see Drechsler 2009a) That too many developing countries do not have it yet need it - indeed that this could even define the euphemism of "developing" (whatever that means, and whither), is likewise obvious. (Cf. http://www.unpan.org/, if only for the problem, not necessarily for the remedy.)

Now, one could see it either way: Developing countries do not have sufficient administrative capacity and thus need to be motivated or forced to move towards global-Western PA, or - either for now or in general - seeing that this ostensibly does not work (in many places at least), they need 
to develop optimal capacity according to their own governance system and general context. And this is especially so because the track record of the more or less forced Westernization of Islamic countries, and people, in PA and otherwise, has not exactly been excellent.

As pointed out earlier, in PA today this is all the more so because the goals of good global-Western are moving indeed; some are even highly volatile - privatization, say - and some others have recently become quite questionable as well - transparency as a goal may come to mind. (See Han 2012) But again, even if we go for the ("good") global-Western values - should we not at least look into whether they are perhaps global but not exclusively Western, and whether they could just not be promulgated in a way that is more easily swallowable than Western triumphalism, especially as the times make the latter sound somehow hollow? (Cf. Steiner et al. 2007, 517-540; Maier 1997, 48-50) In other words, should we not ask whether different narratives are possible?

If we even question the universality of ethical goals, however, and of all the great Western accomplishments such as, allegedly at least, "separation of power, sovereignty of the people, representative democracy" (so Winkler 2011), is this not betrayal of Humankind, especially of that outside of the West? And even if it were not, is it not a betrayal of "ourselves" in the West? That quintessential European intellectual, Umberto Eco, has recently written:

Trying to understand other people means destroying the stereotype without denying or ignoring the otherness. - But let us be realistic. These ways of understanding the enemy are the prerogatives of poets, saints, and traitors. Our innermost impulses are of quite another kind. $(2012,18)$

I usually agree with Eco, but here I completely disagree - I even wonder whether this statement is not a ruse. The jump here is way too fast: "other people" are not automatically "the enemy". To try to understand them is not the prerogative of anyone special, but the duty of any autonomous individual - of anyone who lays claim to the tradition of Ancient Greece, the Enlightenment, and Science. If anything is truly enlightened Western, then it is trying to understand the other. That to sometimes go against one's innermost impulses, rather than with them, in fact to go above and beyond them, is what makes Man great, however, is a truly universal value in which Westerners, Confucians and Muslims fully share.

It is true that part of the Western legacy, although perhaps more of the Anglo-American and French variety, rather than the Continental-CEE one, 
is to absolutize itself and proclaim the universality of its achievements (Winkler 2011), but I suggest that in too many a place, this leads to inverted, paradoxical results; that there is more than just a whiff of post-colonialist problems in this position; and once more, that to question oneself is not only, but decidedly, Western. To allow different places different narratives is, I think, more Western than not do so, for whatever this is worth.

But even if to constantly question oneself is too high a demand put to everyone - it is not too high a demand for the world of the university with its unique focus on the interplay of theory and practice. That is what the Western university is about (and what makes it different from a functionalist training camp): Trying to understand, questioning what one knows and takes for certain and granted. In academic PA, I would say that truly Western right now, at this point in time, is to question whether global = Western = good, and to recognize that both in equity and in performance, one can probably progress towards the good on other paths as well. That is what I propose, not more, but certainly not less.

\section{Acknowledgments}

This lecture was delivered on the occasion of my being awarded an honorary doctorate in the social sciences by the Corvinus University of Budapest on 22 February 2013, for which I am humbly grateful. I also presented it later at the Public Management Institute of the Faculty of Social Sciences of the Catholic University of Leuven on 11 March 2013. The lecture style was to some extent retained (such as concerns duktus, personal perspective, and selectivity of sources, which are not meant to represent a survey of the topics covered), which is also suitable for a more discursive, conceptual topic like this. The essay uses parts from several earlier works, all referred to in the text, especially from Drechsler 2014 and Drechsler 2013, which deal with related sub-topics. I would like to avail myself of this opportunity to thank my most important interlocutors regarding NWPA during the last two or three years: Aleksandr Aidarov, Daniel A. Bell, Evan M. Berman, Geert Bouckaert, Marleen Brans, Michiel de Vries, Ingbert Edenhofer, Korel Göymen, Chung-Yuang Jan, György Jenei, Rainer Kattel, Aziz Klebleyev, Andrew Massey, B. Guy Peters, Tiina Randma-Liiv, Allan Rosenbaum, Sor-Hoon Tan, and Rustamjon Urinboyev. I am also grateful to the Leuven audience for a very animated discussion that led to some minor but important revisions. Finally, I most sincerely thank the Corvinus University of Budapest, especially Rector Zsolt Rostoványi, Dean László Trautmann, and again György Jenei, for the magnificent honor and for the event that caused this lecture to be developed. 


\section{Bibliography}

Pure web-based information is not repeated here and is valid as of 13 February 2013.

Ansary, T. (2009): Destiny Disrupted. A History of the Islamic World through Islamic Eyes. New York: Public Affairs.

Aras, B. (2012): Turkey and the Balkans: New Policy in a Changing Regional Environment. German Marshall Fund On Turkey Analysis, 31 October.

Barkey, K. (2008): Empire of Difference. The Ottomans in Comparative Perspective. Cambridge: Cambridge UP.

Bartlett, B. S. (1991): Monarchs and Ministers: The Grand Council in MidCh'ing China, 1723-1820. Berkeley, CA: U of California P.

Bauer, T. (2011): Die Kultur der Ambiguität. Eine andere Geschichte des Islam. Berlin: Verlag der Weltreligionen / Insel.

Bell, D. A. (2011): Singapore: The City of Nation Buildung. In: Bell, D.A. - de-Shalit, A. (ed): The Spirit of Cities. Why the Identity of a City Matters in a Global Age. Princeton, NJ -etc.: Princeton UP, 78-110

Bell, D. A. (2010): China's New Confucianism. Politics and Everyday Life in a Changing Society. $4^{\text {th }} \mathrm{pr}$. Princeton, NJ etc.: Princeton UP.

Berliner, N. et al. (eds) (2010): The Emperor's Private Paradise. Treasuries from the Forbidden City. New Haven, CT - London: Peabody Essex Museum / Yale University Press.

Berman, E. M. (2010): Public Administration in East Asia: Common Roots, Ways and Tasks. In Berman, E. M. et al. (eds): Public Administration in East Asia: Mainland China, Japan, South Korea, Taiwan. Boca Raton, FL: CRC P, 2-32.

Bilefsky, D. (2012). "As if the Ottoman Period Never Ended." The New York Times, 29 October.

Böckenförde, W. (2011): Europa und die Türkei [2005]. In: Wissenschaft, Politik, Verfassungsgericht. Berlin: Suhrkamp, 281-298.

Bossaert, D. - Demmke, C. (2003): Civil Service in the Accession States. New Trends and the Impact of the Integration Process. Mastricht: EIPA.

Bouckaert, G. (2012): Public Sector Performance: Managing Governments by the Numbers. In: Tria, G. - Valott, G. (eds): Reforming the Public Sector: How to Make the Difference? Washington, DC: Brookings, 173-193.

Bouckaert, G. (2011): Public Administration of the Future. Keynote address, $19^{\text {th }}$ NISPAcee Annual Conference, Varna, Bulgaria, 19 May.

Boyer, R. (1994): The Convergence Thesis Revisited: Globalization but still the Century of Nations? In Berger, S. - Dore, R. (eds): National Diversity and Global Capitalism. Ithaca, NY: Cornell UP, 29-59. 
Buruma, I. - Margalit, A. (2004): Occidentalism: A Short History of AntiWesternism. London: Atlantic Books.

Chehabi, H. E. - Linz, J. J. (1998): A Theory of Sultanism 1. A Type of Nondemocratic Rule. In Chehabi, H. E. - Linz, J. J. (eds): Sultanistic Regimes. Baltimore, MD: Johns Hopkins UP, 3-25.

Cheung, A. B. L. (2012): Public administration in East Asia: legacies, trajectories and lessons. International Review of Administrative Sciences 78(2): 209-216.

Cheung, A. B. L. (2010): Checks and Balances in China's Administrative Traditions: A Preliminary Assessment. In: Painter and Peters, 31-43.

Christensen, T. et al. (2012): Imitating the West? Evidence on Administrative Reform from the Upper Echelons of Chinese Provincial Government. Public Administration Review 72(6): 798-806.

Diamond, L. (2013): Why wait for Democracy? The Wilson Quarterly: Winter.

Drechsler, W. (2014): Wang Anshi and the Origins of Modern Public Management in Song Dynasty China. Public Money and Management $34(1)$, in press.

Drechsler W. (2013): 'Islamic' Public Administration: The Missing Dimension in NISPAcee Public Administration Research? In Vintar et al., in press.

Drechsler, W. (2011): Public Administration in Times of Crisis. In Kattel, R. et al. (eds): Public Administration in Times of Crisis. Bratislava: NISPAcee $\mathrm{P}, 15-25$.

Drechsler, W. (2009a): Towards the Law \& Economics of Development: Ragnar Nurkse (1907-1959). European Journal of Law and Economics 28(1): 19-37.

Drechsler, W. (2009b): The Rise and Demise of the New Public Management: Lessons and Opportunities for South East Europe. Uprava - Administration 7(3): 7-27.

Drechsler W. (2004): Governance, Good Governance, and Government: The Case for Estonian Administrative Capacity. Trames 8(4): 388-396.

Drechsler, W. (1997a): On German Geist. Trames 1(2): 65-77.

Drechsler, W. (1997b): Christian Wolff (1679-1754): A Biographical Essay. European Journal of Law and Economics 4(2-3): 111-128.

Drechsler, W. - Kattel, R. (2009): Conclusion: Towards the Neo-Weberian State? Perhaps, but certainly adieu, NPM! The NISPAcee Journal of Public Administration and Policy 1(2): 95-99.

Eco, U. (2012): Inventing the Enemy - and other occasional Writings. London: Harvill Secker.

Elliott, M. (2009): Emperor Qianlong: Son of Heaven, Man of the World. New York: Longman. 
Elman, B. A. (2000): A Cultural History of Civil Examinations in Late Imperial China. Berkeley, CA: U of California P.

Endresen, C. (2011): Diverging images of Ottoman legacy in Albania. In Sindbaeck and Hartmuth, 37-51.

Fähnders, T. (2011): Welcher Konfuzius darf es sein? Frankfurter Allgemeine Zeitung, 1 April.

Filkins, D. (2012). The Deep State. The Prime Minister is revered as a moderate, but how far will he go to stay in power? The New Yorker, March 12: 38-49.

Findley, C. V. (1980): Bureaucratic Reform in the Ottoman Empire. The Sublime Porte, 1789-1922. Princeton, NJ: Princeton UP.

Finkel, C. (2007): Osman's Dream: The Story of the Ottoman Empire 1300-1923. New York: Basic Books.

Fong, M.H. (1983): The Iconography of the Popular Gods of Happiness, Emolument, and Longevity (Fu Lu Shou). Artibus Asiae 44(2/3): 159-199.

Fukuyama, F. (2011): The Origins of Political Order: From Prehuman Times to the French Revolution. New York: Farrar, Straus and Giroux.

Gardner, D. K. (ed) (2007): The Four Books: The Basic Teachings of the Later Confucian Tradition. Indianapolis: Hackett.

Grindle, M. S. (2004): Good Enough Governance: Poverty Reduction and Reform in Developing Countries. Governance 17(4): 525-548.

Grindle, M. S. (2007). Good Enough Governance Revisited. Development Policy Review 25(5): 533-574.

Gülen, F. (2012). Islam und Moderne stehen nicht im Widerspruch. Interview with R. Hermann. Frankfurter Allgemeine Zeitung, 6 December.

Gulrajani, N. - Moloney, K. (2012): Globalizing Public Administration: Today's Research and Tomorrow's Agenda. Public Administration Review 72(1): 78-86.

Han, B.-C. (2012): Transparenzgesellschaft. Berlin: Matthes \& Seitz.

Hanioğlu, M. Ș. (2008): A Brief History of the Late Ottoman Empire. Princeton etc.: Princeton UP.

Hartmann, N. (1949). Nikolai Hartmann. In Philosophen-Lexikon. Handwörterbuchder Philosophie nach Personen 1. Berlin: de Gruyter, 454-471.

Haslip, J. (1973 [1958]): The Sultan. The Life of Abdul Hamid II. London: Weidenfeld and Nicolson.

Heath, P. (ed) (1974): The Philosopher's Alice. New York: St. Martin's Press.

Heper, M. (2001): The State and Bureaucracy - The Turkish Case in Historical Perspective. In Farazmand, A. (ed): Handbook of Comparative and Development Public Administration. $2^{\text {nd }}$ edn. New York: Dekker, 1019-1028.

Jacques, M. (2011): How China Will Change the Way We Think: The 
Case of the State. TransAtlantic Academy Paper Series, February. Kadri, S. (2011): Heaven on Earth. A Journey Through Shari'a Law. London: Bodley Head.

Kostadinova, T. - Neshkova, M. I. (2013): Explaining the Incidence of Administrative Reform in Eastern Europe. In Vintar et al. (eds), in press.

Lerch, W. G. (2012): Die Wende. Frankfurter Allgemeine Zeitung, 23 July. Lotman, J. M. (1971): Problema 'obushenya kulture' kak yeo tipologisheskaya harakteristika. Semeiotiké 5: 167-176.

MacGregor, N. (2011): A history of the World in 100 Objects. London: Allen Lane.

Maier, H. (1997): Wie universal sind die Menschenrechte? Freiburg: Herder. Mencius (2008): Mengzi. With selections from traditional commentaries. Van Norden, B. W., tr. and ed. Indianapolis, IA etc.: Hackett.

Michels, R. (1911): Zur Soziologie des Parteiwesens in der Modernen Demokratie: Untersuchungen über die oligarchischen Tendenzen des Gruppenlebens. Leipzig: Klinkhardt.

Miyazaki I. (1981): China's Examination Hell: The Civil Service Examinations of Imperial China. New Haven, CT: Yale UP.

Nizām al-Mulk (1960): The Book of Government or Rules for Kings. Syiāsátnāma or Siyar al-Mulk. H. Drake, tr. London: Routledge \& Kegan Paul.

Nurkse, R. (1952): Trade fluctuations and buffer policies of low-income countries. Kyklos 12(3): 141-154; Epilogue: 244-265.

Nurkse R. (1964 [1953]) Problems of Capital Formation in Underdeveloped Countries. $9^{\text {th }}$ impr. Oxford: Basil Blackwell.

Osnos, E. (2012): Boss Rail. The disaster that exposed the underside of the boom. The New Yorker, 22 October.

Painter, M. - Peters, B.G. (eds) (2010): Tradition and Public Administration. London: Palgrave Macmillan.

Pollitt, C. - Bouckaert, G. (2011): Public Management Reform. A Comparative Analysis: New Public Management, Governance, and the Neo-Weberian State. $3^{\text {rd }}$ edn. Oxford: Oxford UP.

Pollitt, C. - Bouckaert, G. (2004): Public Management Reform. A Comparative Analysis. $2^{\text {nd }}$ edn. Oxford: Oxford UP.

Public Administration Review (2010). R. O'Leary - D. M. Van Slyke (eds): Special Issue on the Future of Public Administration in 2020. 70(Supplement s1).

Randma-Liiv, T. - Kruusenberg, R. (2012): Policy Transfer in Immature Policy Environments: Motives, Scope, Role Models and Agents. Public Administration and Development 32(2): 154-166.

Reinkowski, M. (2011): The Ottoman Empire and South Eastern Europe from a Turkish perspective. In Sindbaek and Hartmuth, 21-36.

Reinkowski, M. (2005): Die Dinge der Ordnung. Eine vergleichende Untersuchung über die osmanische Reformpolitik im 19. Jahrhundert. München: Oldenbourg. 
Schulz, O. (2011): Ein Sieg der zivilisierten Welt? Die Intervention der europäischen Großmächte im griechischen Unabhängigkeitskrieg (1826-1832). Münster: Lit.

Sezen, S. (2011): International versus domestic explanations of administrative reforms: the case of Turkey. International Review of Administrative Sciences 77(2): 322-346.

Siemons, M. (2011): Zum Denken bitte in den Hinterhof. Frankfurter Allgemeine Zeitung, 26 April.

Siemons, M. (2010): China und der Konfuzianismus: Kotau mit Krawatte. Frankfurter Allgemeine Zeitung, 1 November.

Sindbaeck, T. and M. Hartmuth (eds) (2011). Images of Imperial Legacy. Modern discourse on the social and cultural impact of Ottoman and Habsburg rule in Southeast Europe. Münster: Lit.

Steiner, H. J. et al. (2007): International Human Rights in Context. $3^{\text {rd }}$ edn. Oxford: Oxford UP.

Stolleis, M. (2003). Der menschenfreundliche Ton. Zwei Dutzend Geschichten von Johann Peter Hebel mit kleinem Kommentar. Frankfurt/Main: Insel.

Tuğal, C. (2009). Passive Revolution. Absorbing the Islamic Challenge to Capitalism. Stanford, CA: Stanford UP.

Urinboyev, R. (2011): Law, Social Norms and Welfare as Means of Public Administration: Case Study of Mahalla Institutions in Uzbekistan. NISPAcee Journal of Public Administration and Policy 4(1): 33-57.

Vintar, M. et al. (ed) (2013): The Past, Present and Future of Public Administration in Central and Eastern Europe, Central Asia, and the Caucasus: Twenty Years of NISPAcee, 1992-2012. Bratislava: NISPAcee $P$, in press.

Wang Anshi (1935): The Wan Yen Shu, or Memorial of a Myriad Words [1058]. In: Williamson, H.R. Wang An Shih - a Chinese Statesman and Educationalist of the Sung Dynasty 1. London: Probsthain, 48-84.

Weber, M. (1986): Gesammelte Aufsätze zur Religionssoziologie 1. $8^{\text {th }}$ edn. Tübingen: Mohr Siebeck.

Weber, M. (1922): Grundriß der Sozialökonomik 3: Wirtschaft und Gesellschaft. Tübingen: Mohr Siebeck.

Winkler, H. A. (2011). Wo fängt der Westen an, wo hört der Osten auf? Interview with C. Seidl. Frankfurter Allgemeine Zeitung, 24 December.

Wolff, C. (1985): Oratio de Sinarum philosophia practica / Rede über die praktische Philosophie der Chinesen. Albrecht, M. (ed). Hamburg: Meiner.

Yesilkagit, K. (2010): The Future of Administrative Tradition: Tradition as Ideas and Structure. In Painter and Peters, 145-157. 


\section{Working Papers in Technology Governance and Economic Dynamics}

The Other Canon Foundation, Norway, and the Technology Governance program at Tallinn University of Technology (TUT), Estonia, have launched a new working papers series, entitled "Working Papers in Technology Governance and Economic Dynamics". In the context denoted by the title series, it will publish original research papers, both practical and theoretical, both narrative and analytical, in the area denoted by such concepts as uneven economic growth, techno-economic paradigms, the history and theory of economic policy, innovation strategies, and the public management of innovation, but also generally in the wider fields of industrial policy, development, technology, institutions, finance, public policy, and economic and financial history and theory.

The idea is to offer a venue for quickly presenting interesting papers scholarly articles, especially as preprints, lectures, essays in a form that may be developed further later on - in a high-quality, nicely formatted version, free of charge: all working papers are downloadable for free from http://hum.ttu.ee/tg as soon as they appear, and you may also order a free subscription by e-mail attachment directly from the same website.

The working papers published so far are:

1. Erik S. Reinert, Evolutionary Economics, Classical Development Economics, and the History of Economic Policy: A Plea for Theorizing by Inclusion.

2. Richard R. Nelson, Economic Development from the Perspective of Evolutionary Economic Theory.

3. Erik S. Reinert, Development and Social Goals: Balancing Aid and Development to Prevent 'Welfare Colonialism'.

4. Jan Kregel and Leonardo Burlamaqui, Finance, Competition, Instability, and Development Microfoundations and Financial Scaffolding of the Economy.

5. Erik S. Reinert, European Integration, Innovations and Uneven Economic Growth: Challenges and Problems of EU 2005.

6. Leonardo Burlamaqui, How Should Competition Policies and Intellectual Property Issues Interact in a Globalised World? A Schumpeterian Perspective

7. Paolo Crestanello and Giuseppe Tattara, Connections and Competences in the Governance of the Value Chain. How Industrial Countries Keep their Competitive Power

8. Sophus A. Reinert, Darwin and the Body Politic: Schäffle, Veblen, and the Shift of Biological Metaphor in Economics

9. Antonio Serra, Breve Trattato / A Short Treatise (1613) (available only in hardcopy and by request). 
10. Joseph L. Love, The Latin American Contribution to CenterPeriphery Perspectives: History and Prospect

11. Ronald Dore, Shareholder capitalism comes to Japan

12. Per Högselius, Learning to Destroy. Case studies of creative destruction management in the new Europe

13. Gabriel Yoguel, Analía Erbes, Verónica Robert and José Borello, Diffusion and appropriation of knowledge in different organizational structures

14. Erik S. Reinert and Rainer Kattel, European Eastern Enlargement as Europe's Attempted Economic Suicide?

15. Carlota Perez, Great Surges of development and alternative forms of globalization

16. Erik S. Reinert, lulie Aslaksen, Inger Marie G. Eira, Svein Mathiesen, Hugo Reinert \& Ellen Inga Turi, Adapting to Climate Change in Reindeer Herding: The Nation-State as Problem and Solution

17. Lawrence King, Patrick Hamm, The Governance Grenade: Mass Privatization, State Capacity and Economic Development in Postcommunist and Reforming Communist Societies

18. Reinert, Erik S., Yves Ekoué Amaïzo and Rainer Kattel, The Economics of Failed, Failing and Fragile States: Productive Structure as the Missing Link

19. Carlota Perez, The New Technologies: An Integrated View

20. Carlota Perez, Technological revolutions and techno-economic paradigms

21. Rainer Kattel, Jan A. Kregel, Erik S. Reinert, The Relevance of Ragnar Nurkse and Classical Development Economics

22. Erik S. Reinert, Financial Crises, Persistent Poverty, and the Terrible Simplifiers in Economics: A Turning Point Towards a New "1848 Moment"

23. Rainer Kattel, Erik S. Reinert and Margit Suurna, Industrial Restructuring and Innovation Policy in Central and Eastern Europe since 1990

24. Erkki Karo and Rainer Kattel, The Copying Paradox: Why Converging Policies but Diverging Capacities for Development in Eastern European Innovation Systems?

25. Erik S. Reinert, Emulation versus Comparative Advantage: Competing and Complementary Principles in the History of Economic Policy

26. Erik S. Reinert, Capitalist Dynamics: A Technical Note

27. Martin Doornbos, Failing States or Failing Models?: Accounting for the Incidence of State Collapse

28. Carlota Perez, The financial crisis and the future of innovation: $A$ view of technical change with the aid of history 
29. Rainer Kattel and Annalisa Primi, The periphery paradox in innovation policy: Latin America and Eastern Europe Compared

30. Erkki Karo and Rainer Kattel, Is 'Open Innovation' Re-Inventing Innovation Policy for Catching-up Economies?

31. Rainer Kattel and Veiko Lember, Public procurement as an industrial policy tool - an option for developing countries?

32. Erik S. Reinert and Rainer Kattel, Modernizing Russia: Round III. Russia and the other BRIC countries: forging ahead, catching up or falling behind?

33. Erkki Karo and Rainer Kattel, Coordination of innovation policy in the catching-up context: Estonia and Brazil compared

34. Erik S. Reinert, Developmentalism

35. Fred Block and Matthew R. Keller, Where do Innovations Come From? Transformations in the U.S. Economy, 1970-2006

36. Erik S. Reinert \& Arno Mong Daastøl, Production Capitalism vs. Financial Capitalism - Symbiosis and Parasitism. An Evolutionary Perspective and Bibliography

37. Erik S. Reinert, Zeitgeist in Transition: An Update to How rich countries got rich...and why poor countries stay poor

38. Marek Tiits \& Tarmo Kalvet, Nordic small countries in the global high-tech value chains: the case of telecommunications systems production in Estonia

39. Erik S. Reinert, Mechanisms of Financial Crises in Growth and Collapse: Hammurabi, Schumpeter, Perez, and Minsky

40. Erik S. Reinert, Economics and the Public Sphere

41. Osvaldo Urzúa, Emergence and Development of KnowledgeIntensive Mining Services (KIMS)

42. Carlota Perez, Innovation systems and policy: not only for the rich?

43. Peer Vries, Does wealth entirely depend on inclusive institutions and pluralist politics?

44. John A. Mathews, The renewable energies technology surge: A new techno-economic paradigm in the making?

45. Andrés Cárdenas O'Farrill, Natural resource and service-based export performance: Cuba after 1989

46. Ali Kadri, The Political Economy of the Syrian Crisis

47. Erik S. Reinert, Jacob Bielfeld's "On the Decline of States" (1760) and its Relevance for Today

48. Erik S. Reinert, Primitivization of the EU Periphery: The Loss of Relevant Knowledge

49. Erik S. Reinert and Rainer Kattel, Failed and Asymmetrical Integration: Eastern Europe and the Non-financial Origins of the European Crisis 
50. Wolfgang Drechsler, Three Paradigms of Governance and Administration: Chinese, Western and Islamic

The working paper series is edited by Rainer Kattel (kattel@staff.ttu.ee), Wolfgang Drechsler (drechsler@staff.ttu.ee), and Erik S. Reinert (reinert@staff.ttu. ee), who all of them will be happy to receive submissions, suggestions or referrals. 